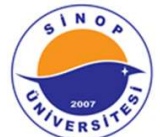

Sinop Üniversitesi

Sosyal Bilimler Dergisi

5ISSN 2547-989X
Araștırma Makalesi
Sinop Üniversitesi Sosyal Bilimler Dergisi, 5 (2), 365-385

Geliş Tarihi:05.10.2021 Kabul Tarihi:30.11.2021

Yayın: 2021 Yayın Tarihi:30.11.2021

https://doi.org/10.30561/sinopusd.1005000

\title{
BYZANTINE GLAZED WARE FROM SESTOS-AKBAŞ IN THE THRACIAN CHERSONESOS*
}

Ayşe ÇAYLAK TÜRKER**

\begin{abstract}
The castle of Sestos-Akbaş is located on the Hellespont coast of the Yalova Val-ley within the Thracian Chersonesos. The location of the castle creates natural defense. The ancient city of Sestos is localized in the place where the castle in Akbaş is located Ak-baş Port in the southeast of the castle is an important commercial and military port. The Byzantine glazed pottery items constituting the subject of this study are the sherds that were detected in this area. The finds include sherds with white and red paste. The group with white paste is small in number. Vessels decorated in incised technique are considered among the glazed pottery items with red paste. Specimens of the Aegean and Zeuxippus ware were detected among the vessels with an incised decoration. By evaluating the distributional areas of the Zeuxippus ware, they are considered important indications of the trade among the Mediterranean Sea, the Aegean Sea, and the Black Sea in the late Byzan-tine period. Constituting the most considered assemblage in the Byzantine settlement areas on the coast of the Hellespont, these pottery items indicate the important position of the Hellespont in the trade between the Mediterranean Sea and the Black Sea. Tripod traces which indicate production are frequently detected in these pottery items. Tripod traces were also determined at the centre on the interior of the vessel in the sherds that we found in the region which was the port of the ancient
\end{abstract}

* This article was presented at the 'Glazed Wares in the Black Sea and Mediterranean as a Source fort he Studies of Byzantine Civilization, International Research Seminar' in Sevastopol, 2014 but not published.

** Prof. Dr., Fen Edebiyat Fakültesi Sanat Tarihi Bölümü, ayseturker@comu.edu.tr https://orcid.org/0000-0002-8030-2273 Çanakkale, Türkiye. 
city of Sestos and that constitute the subject of this study. Besides these sherds, which indicate defective production, semi-finished sherds left unglazed after they had been biscuit fired and slipped or after a composition had been incised on the slip are also available among the finds. Defective and semi-finished sherds are essential in that they indicate a production site of these vessels probably in the Hellespont.

Keywords: Sestos, Akbaş, Byzantine, Glazed ware, Hellespont

\section{Trakya Khersonesos'undaki Sestos- Akbaş'dan Bizans Dönemi Sırlı Seramikleri}

\section{Öz}

Akbaş- Sestos Kalesi, Trakya Kersonesos’unda, Yalova vadisinin Çanakkale Boğazı kıyısında bulunur. Kale, Boğaz geçişlerinin kontrolü için oldukça stratejik bir noktada yer almaktadır. Antik Sestos şehri de Akbaş’taki kalenin bulunduğu alana lokalize edilir. Kalenin güneydoğusundaki Akbaş Limanı önemli bir ticari ve askeri limandır. Bu çalışmanın konusunu oluşturan Bizans sırlı seramikleri bu alanda tespit edilmiş parçalardır. Buluntular arasında beyaz ve kırmızı hamurlu seramikler yer alır. Beyaz hamurlu grup sayıca azdır. Yoğun grubu ise İstanbul'daki buluntu yerlerine göre “Zeuxippus Ware” olarak adlandırılan seramik grubu oluşturur. Zeuksippus grubundaki seramiklerin dağılım alanları, Akdeniz, Ege ve Karadeniz arasındaki ticaretin geç Bizans dönemindeki önemli göstergeleri olarak değerlendirilirler. Çanakkale Boğazı kıyısındaki Bizans yerleşim alanlarında en yoğun buluntu grubunu oluşturan bu seramikler, Akdeniz ve Karadeniz arasındaki ticarette Çanakkale Boğazının önemli konumuna işaret eder. Boğaz kıyısındaki yerleşimlerde yoğun olarak tespit edilen seramiklerde ise sıklıkla üretime işaret eden üçayak izleri tespit edilmektedir. Sestos antik kentinin limanı olan bölgede tespit ettiğimiz ve bu çalışmanın konusunu oluşturan parçalarda da kabın iç yüzünde, merkezde üçayak izleri tespit edilmiştir. Hatalı üretime işaret bu parçaların yanı sıra bisküvi pişirimi yapılıp astarlandıktan sonra ya da astar üzerine kompozisyon kazındıktan sonra sırlanmadan bırakılmış yarı mamul parçalar da buluntular arasında yer alır. Hatalı ve yarı mamul parçalar bu kapların olasılıkla Çanakkale Boğazı'ndaki bir üretim yerine işaret ettiği için önemlidir.

Anahtar Kelimeler: Sestos, Akbaş, Bizans, Seramik, Çanakkale 


\section{Introduction}

The Black Sea and the Mediterranean Sea were important economic areas in the Byzantine period. The Hellespont, a natural maritime line that formed in the north-east - south-west direction, was of profound importance in the productionconsumption relationships between these areas. From the historical data, it is understood that the strait preserved this important location throughout the Byzantine Period. According to these data, archaeological surveys were conducted regarding the Byzantine settlements in the Hellespont and on the valleys that reached the Hellespont as well as their patterns. According to the data we obtained in these studies, one of the common characteristics of the Byzantine coastal cities in the Hellespont is their possession of a natural port on the coast of the strait. The locations of these ports are gener-ally the mouths of the valleys generated by the streams which reached the Hellespont. Some of the surveys we carried on in the region in the Byzantine period comprised the studies on the Yalova Valley and in the ancient city of Sestos. In these studies, it was also aimed to evaluate the pottery finds so as to determine the area where the Byzantine settlement in Sestos had spread. Examination of the glazed sherds among the pottery finds will constitute the sub-ject of this study.

\section{Sestos-Akbaş Castle and Finding Places of the Pottery}

The castle of Sestos-Akbas is located on the Hellespont coast of the Yalova Valley within the Thracian Chersonesos. The castle is located at an altitude of around $80 \mathrm{~m}$ at the central point of the land with both sides sheltered on the north-east-facing plateau at an altitude of approximately $100 \mathrm{~m}$ at the south-western margin of the Yalova Valley. On the sea-facing side of the plateau are very steep rocky areas. Its northern and southern coasts are also quite steep. The location of the castle creates natural defense. The ancient city of Sestos is localized in the place where the castle in Akbaş is located (Isaac 1986: 197). 
Some of the surveys we carried on in the region to document the military geography and defensive structures of the Hellespont in the Byzantine period comprised the studies on the Yalova Valley and in the ancient city of Sestos ${ }^{1}$. In these studies, it was also aimed to evaluate the pottery finds to de-termine the area where the Byzantine settlement in Sestos had spread. Examination of the glazed sherds among the pottery finds will constitute the subject of this study.

The castle has a polygonal plan consisting of the walls that follow the high points of the land. It has four towers, with each of them in the south-west, south-east, north-east, and north-west. According to the material and technical properties, it was determined that the castle had undergone four different construction phases. The first one is detected at Tower Nu. 1 in the southwest of the castle, on the wall extending eastwards from Tower $\mathrm{Nu}$. 1, and at Tower $\mathrm{Nu}$. 3. This wall technique is parallel with the material and technique on the long wall constructed by Justinian on the isthmus of the Thracian Chersonesos (Crow 1995: 109-124; Greatrex 1995: 125129). The historical data also support these findings. Procopius indicated a castle that had been constructed in this area by Emperor Justinian (Dewing 1971: 303). Accordingly, the first construction phase we detected in the castle can be dated to the sixth century.

The material and technical properties viewed on the walls of the castle indicate that three different construction phases were present in the castle after the sixth century. Accordingly, the second construction phase that could be detected in the castle is viewed in the upper part of the walls of Tower Nu.1 in the southwest, at Tower Nu. 2, and on the defensive wall connected with Tower Nu. 3 in the northeast from Tower Nu. 2. This phase is characterized through the use of the hidden brick technique on the brick bands between the rows of stones. Moreover, the cloisonné technique can be detected, although in a limited fashion. The walls constructed with

\footnotetext{
${ }^{1}$ About the plan characteristics and construction phases of the castle, Türker 2014: 1-11
} 
the alternate technique in the Byzantine architecture are visible as of the fourth century. However, the implementation of the cloisonné technique and the hidden brick technique begin to be seen as of the eleventh century. Accordingly, the second construction phase detected in the castle with the data can be dated to the eleventh to the twelfth centuries. In the castle are two different construction phases belonging to the period after the Byzantine period, probably to the Ottoman period.

Inside the castle is some embankment that reaches about $5 \mathrm{~m}$ today, and the traces of the buildings in this area are invisible. However, architectural plastic items conserved in the Yalova Village have been unearthed in Akbaş locality, were documented during our surveys. The works with a liturgical function constitute an important group among the architectural plastic items. They are the most significant archaeological data indicating the existence of a religious institution in or around the castle in Akbaş.

To understand the range of the settlement, systematic surveys were carried out in the areas located in the northeast and southwest of the castle. These studies were conducted at two stages. At the first stage, an area of $150 \mathrm{~m}$ in diameter, with the castle being the center, was examined. Mortared wall fragments were detected at a distance of approximately $118 \mathrm{~m}$ in its south-west, with the castle being the center. Painted, glazed and unglazed pottery sherds of the early Christian and Byzantine periods were documented at moderate density in this area.

At the second stage, about $540 \mathrm{~m}$ in diameter, with the castle being the center, was examined. The studies at this stage were conducted in two areas. The first area consisted of the altitudes between about $80 \mathrm{~m}$ to $75 \mathrm{~m}$, where the castle was located, and $35 \mathrm{~m}$. Some three wall fragments were documented in this area. Of them, the first one is found about $310 \mathrm{~m}$ to the northeast of the center of the castle at an altitude of about $35 \mathrm{~m}$ on the border of the hill. The second wall is $230 \mathrm{~m}$ to the northwest of the center of the castle at an altitude of about $40 \mathrm{~m}$. This wall is also located on the border of the hill, and it has identical qualities with the wall in the northeast. The third wall fragment is $260 \mathrm{~m}$ to the west of the center of the castle and 
at an altitude of $45 \mathrm{~m}$. These wall fragments must have probably belonged to the external defensive line of the castle.

The second area consisted of the fields approximately between the altitudes of $5 \mathrm{~m}$ and $15 \mathrm{~m}$ at a distance of about $350 \mathrm{~m}$ as the crow flew in the eastern and south-eastern directions from the center of the castle. During the studies in this area, considerable construction materials indicating that a building of the Byzantine Period had been dismantled were documented. Among the pottery, rim sherds of redslipped and painted pottery, dated to the fifth to the seventh centuries, were documented at moderate density. The handle and rim sherds of commercial cargo containers dated to the twelfth century and glazed pottery items are considerable. The data we detected show that the center of the Byzantine settlement in Akbaş was on the hill and that there were workshops for trade by the seaside. The Byzantine glazed pottery items constituting the subject of this study are the sherds that were detected in this area.

\section{Glazed Ware}

The finds include sherds with white and red paste. The group with white paste is small in number. All these sherds except for one of them are rim and base sherds of bowl- and plate-type vessels. However, one of the sherds is an edge sherd of a lid. Specimens of the vessels belonging to GWW I-III are detected among the pottery with white paste. The only sherd likely to be evaluated within GWW I is the base sherd of a bowl (fig. 1.1). The paste is in the shade of pinkish white (5YR7/6), hardly fired, moderately firm, and sand- and lime-tempered. The interior of the vessel is slipped, and the slip is in a little darker shade than the paste. No decoration is seen on the sherd, only the interior of which is glazed in light yellow. By evaluating it with the analogues among the finds from Saraçhane, it can be dated to the eighth century (Hayes 1992: 15)².

${ }^{2}$ About Gülpınar finds of GWW I and II see. Böhlendorf-Arslan 2018:287 
Hardly fired, moderately firm, and sand- and lime-tempered white paste is detected in two bowl base sherds which are likely to be evaluated within GWW II

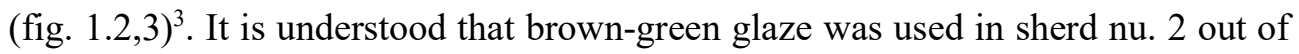
them; however, the glaze has been impaired. A white slip layer can be perceived beneath the glaze. On the other hand, the colorless glaze was applied without any slip in sherd nu. 3. The analogues in Saraçhane are dated to the period between the ninth and twelfth centuries (Hayes 1992:18).

In the sherds likely to be evaluated within GWW III (fig. 1.4, fig.7.55, fig. $1.5,6$, fig. 7.58), the paste is underfired, porous, and large and densely stone- and chamotte-tempered. In one of the sherds (fig.1.4), the green glaze was used on the interior, whereas it can be detected on the exterior that pink paint was smeared in the form of a wide band on the rim by means of a brush. This is not characteristic of GWW. In two sherds (fig.7.55, fig. 1.5,), it is understood that glazes in different colors were used on the interior and the exterior of the vessels. Sherd nu. 55 (fig. $7.55)$ contains light yellow glaze on the interior and brown glaze on the exterior. The glaze on the exterior was applied to cover the base of the vessel too. In sherd nu. 5 (fig.1.5), the yellow glaze on the interior and the green glaze on the exterior were applied without any slip. On the other hand, both the interior and the exterior were green glazed in sherd nu. 6 (fig. 1.6). One of the sherds belongs to the brown-painted and green-glazed pottery (fig. 7.58). Analogues of these pottery items in GWW III are dated to the eleventh to the twelfth centuries (Hayes 1992: 30).

Vessels decorated in incised technique are considered among the glazed pottery items with red paste. Specimens of the Aegean and Zeuxippus ware were detected among the vessels with an incised decoration. The sherds of the Aegean ware

\footnotetext{
${ }^{3}$ The production center of white ware is shown as Istanbul. See. Hayes 1992:12; Armstrong 2001:57. Later studies also provide data to support this view see. Megaw-Jones 1983:258; Waksman and Girgin 2008:467; Vroom 2006:163. In addition Results of a recent study on GWW II discuss the Vezneciler workshop and the evidence for production there see. Waksman 2021:73 and fig 13. For some new finds of GWW also see. Çömezoğlu-Uzbek 2019:100 and İnanan and Seçkin 2021:440.
} 
are the rim and base sherds of bowl- and plate-type vessels. In all sherds, the paste is tile red (5YR6/10), moderately firm, and large and densely stone- and limestonetempered. The slip applied to the interior and, partially, to the exterior of the vessels is cream. The light-yellow glaze was applied to one of the sherds (fig. 1.7), while the green monochrome glaze was applied to the other sherds (fig. 1.8-11, fig 2.12-14). Incised lines and the motif called the spike motif can be detected on the broken sherds (fig.1.10, 11). On the other hand, one of the sherds contains incised lines probably be-longing to a fish figure together with the spike motif (fig.1.10) ${ }^{4}$. The circular incised lines on sherds nu. 8, 9 (fig. 1.8,9), and 12 (fig.2.12) remind of the vessels with a medallion composition (Mercangöz 2013: 25-58; Papanikola-Bakirtzi 1999: 54, fig. 44).

Called Aegean Ware in the findings from Saranda Kolonnes, these vessels are dated to the early thirteenth century by Megaw (1975). However, it is determined that their prototypes in terms of both form and decoration were produced in the second half of the twelfth century. Specimens of the Aegean ware were also detected in the Crimea besides the settlements on the Aegean and Mediterranean coasts ${ }^{5}$. We also found the specimens of the Aegean ware in Kepez, Madytos, Koila, Gallipoli, and Çokal in our surveys in the Hellespont, which qualified as an important watercourse in the commercial relations between the Black Sea and the Mediterranean $\mathrm{Sea}^{6}$. These items, which are surface finds, can be dated to the late twelfth century depending on their analogues.

Specimens of the vessels classified as Classes I and II by Megaw were detected among the sherds in the Zeuxippus group ${ }^{7}$. The striking features of these pot-

\footnotetext{
${ }^{4}$ For similar composition with fish and spike motif see. Doğer 2000: 46-47.

${ }^{5}$ For the distributional area of the vessels and the specimens in İzmir Archaeology Museum, Doğer 2000: 13

${ }^{6}$ A base sherd from Arisbe in the Hellespont see. Kontogiannis and Böhlendorf-Arslan 2021: şekil $1 \mathrm{C}$.

${ }^{7}$ About finding places of Zeuxippus and Zeuxippus family see. İnanan 2014; BöhlendorfArslan 2004, Teil III. Karte 4. In addition a new evaluation about the production centers of
} 
tery items are their quality paste and their brilliant and quality glaze, which was applied in the form of a thick layer as in the original Zeuxippus ware. Their paste is in the shade of tile red and densely and small limestone-, mica-, and sand-tempered.

Decoration compositions comprised of a single circle at the center (fig. 2.15) and two (fig. 2,16, 17) or three (fig.2.18) concentric circles are seen on the light, yellow-glazed base sherds in the Class I group ${ }^{8}$. They are circles that are incised with thin or thick lines (fig. 2.19). A chevron motif is present in the circle at the center in some specimens (fig. 3.20) ${ }^{9}$. In one of the specimens, lines that roughly create an Sform and combed lines are alternately repeated on the wall that remains between the concentric circles at the center and the rim of the plate (fig. 3.21) (Papanikola-Bakirtzi 2007: 73, 95; Türker 2013: 369, fig. 9.62; Doğer 2012: tablo 28.143).

Incised lines consisting of one or two lines to tour the rim on the interior and the exterior were included in the rim sherds (fig. 3.22-26). In two sherds, a composition that comprised vertical incised lines was applied to the exterior, although there were two incised lines that toured the rim on the interior (fig. 3.27-28) ${ }^{10}$. A simple composition consisting of incised lines at the rim was placed in the area which was bordered by two incised lines in two sherds. The first one comprises the incised lines which form spirals (Papani-kola-Bakirtzi 2007: 20) (fig. 4.29), whereas the other one consists of the notches placed in parallel with each other (Papanikola-Bakirtzi 2007: 133, nu.146) (fig. 4.30). On the other hand, no incised decoration is available on the exterior. The arrangements consisting of concentric circles at the center on the orange monochrome glazed base sherds (fig. $4.31,32$ ) sometimes start from the center

the ware see. Waksman 2021:67-69. For chemical compositions of paste see. Waksman and François 2004-2005:657-665. A new finding place of this ware in the Marmara Region see. İnanan and Seçkin 2021:440-4. For other samples from Marmara see. François 2003, 306308; Özkul-Fındık 2014, 99-121.

${ }^{8}$ For an analogous specimen with three concentric circles, Megaw 1968: 63, pl. $15 \mathrm{~b}$.

${ }^{9}$ For similar applications with a chevron motif see. Megaw 1968: pl. 14.c, 15.a; PapanikolaBakirtzi 2007: 55, n.131; Doğer 2012: 157, fig. 209; 165, fig. 244.

${ }^{10}$ For similar composition see. Doğer 2012:tablo 40; Böhlendorf-Arslan 2004: tafel 79 (Ilion). 
and join the outer circle (fig. 4.33) ${ }^{11}$. Nevertheless, most of the sherds are broken and the composition order cannot be detected (fig. 4.34-36, fig. 7.59). Besides the arrangement which comprises incised lines on the interior and the exterior at the rim sherds (fig. 4.37, 38), a slip painting decoration is present at the rim on the exterior in a specimen (fig. 5.39). In two green monochrome glazed base sherds, it is understood that an arrangement consisting of incised lines was also included in the section between the concentric circles at the center and the rim of the plate. Analogous specimens can be detected among the finds from Anaia (Mercangöz 2013: 35, fig. I.7.a). Specimens of the green-glazed sherds were found in large numbers in our study area; however, the glazes on most sherds were shed. Nevertheless, analogues in terms of form and glaze color can be detected among the finds from Thrace and Anaia. At the excavations in Thrace, their analogues are evaluated in the thirteenth century $(\mathrm{Pa}-$ panikola-Bakirtzi 2007: 143, nu.160; Mercangöz 2013: 37, fig. I.10.a, b).

The specimens of the group determined as Class II by Megaw are few-er than those of the first group ${ }^{12}$. The paintings in the form of brown spots are characteristic of these pottery items. The vessels are covered with transparent glaze or with the glaze in the shade of pale yellow. Their decoration compositions resemble those of the sherds in Class I. An arrangement that comprises concentric circles at the center is seen on the interior of the vessel (fig. 4, 40-41). There are two sherds on which the circle at the center out of these circles contains a chevron motif (fig. 5.42, fig.7.54). Even though decorations consisting of incised lines are detected in the section between the circles at the center and the rim of the vessel, the broken sherds do not considerably give an idea about the composition order (fig.5.43). In two sherds, the center of the vessel contains an arrangement that consists of wavy lines (fig. 5.44, 45). In the second one, the space between the medallions bordering the composition is also filled with vertical lines (fig. 5.45). Sherds with a similar arrangement are

${ }^{11}$ For similar decoration see. Köroğlu and İnanan 2018:tablo 1b.

${ }^{12}$ For some other samples of this ware found in the Marmara Region see. Auzepy 2006:384, 393,385 . 
among the finds from Anaia (Mercangöz 2013: 35, fig. I.7.a). It is under-stood that a free arrangement was included in one of the base sherds in this group, which was enriched with brown painting; however, only a small part of the composition is visible on the broken sherd. It might be predicted that this sherd had a similar composition to the base sherd among the finds from Gülpınar (Yenişehirlioğlu 1989: fig. 15. G44, fig. 18). The rim sherds in this group display richer decoration compositions than those in the first group. Besides the arrangements consisting of incised lines (fig. 5.46, fig. 6.47), the area bordered by incised lines also contains folded branches (fig. 6.48, fig. 7.56) and arrangements that comprise S-forms (fig. 6. 49).

Specimens of closed vessel forms are generally found in a small number in the Zeuxippus ware. Three jug sherds were detected among the finds from Sestos. A sherd among the finds is understood to have been comprised of a hollow handle attached to a narrow rim. Small notches repeated at specific intervals are found on the handle. The orange glaze, which is characteristic of the second group of ZW I, was applied over the white slip. It probably had a similar function to that of the vessels defined as wine-thief (fig. 6.50, fig. 7.50) ${ }^{13}$.

\section{Conculusion}

Called Zeuxippus Ware according to their findspots in Istanbul, these pottery items are dated to the transitional period between the Komnenos and Paleologos Families and evaluated as the products of the period when the Latins had a say in the Byzantine trade ${ }^{14}$. By evaluating the distributional areas of the pottery, they are considered important indications of the trade among the Mediterranean Sea, the Aegean

${ }^{13}$ Cottica 1998: 81-90; Cottica 2007: 272 272, fig. 14.6-7; Bass - Doorninck 1982: 181-182, fig. 8; Cottica 2005: fig.5.11. For unglazed example from Dyadovo and Rhodopes (Bulgaria), Monemvasia (Greece), Novgorod and Novogrudok (Russia), Marseilles (France) and another function see Mastoropoulos 1988 and Koval (poster). In addition analogous hol-low handles can also be detected among the vessels called puzzle cups; however, the rim was also formed to be hollow in these vessels, along with the handle. See, A Guide to the Classiffication of Medieval Ceramic Forms Medieval Pottery Research Group, Oxford 1998: 6.2.8.

${ }^{14}$ About the view that this fashion continued in the Paleologian period see Papanikola - Bakirtzis and Waksman 2015:227-248. 
Sea, and the Black Sea in the late Byzantine period. Constituting the most considerable assemblage in the Byzantine settlement areas on the coast of the Hellespont, these pottery items indicate the important position of the Hellespont in the trade between the Mediterranean Sea and the Black Sea. Sherds of the pottery in the Zeuxippus group are documented in Karaağaçtepe Madytos, Koila, Ilgardere-Hisarlık, Gallipoli, Kalanura, Hexamilion, Yülüce, Kalealtı, Kevgirçeşme, and Çokal out of the settlements in the Thracian Chersonese as well as in Troia, Akköy, Çamköy-Asarlıktepe, Intepe, Kepez, Yağcılar, Karacaören, Lampsacus, Şevketiye-Asarlık and Kocayayla-Sapan Hisar out of the settlements on the Anatolian coast of the Strait ${ }^{15}$. Tripod traces which indicate production are frequently detected in these pottery items. Tripod traces were also determined at the center on the interior of the vessel in the sherds that we found in the region which was the port of the ancient city of Sestos and that constitute the subject of this study (fig. 2.19, fig. 4.31, 33, fig. 5.44, fig. 7.55). Besides these sherds, which indicate defective production, semi-finished sherds left unglazed after they had been biscuit fired and slipped or after a composition had been incised on the slip (fig. 6.51,52) are also available among the finds. Defective and semi-finished sherds are essential in that they indicate a production site of these vessels probably in the Hellespont.

\section{Bibliography}

Armstrong P. (2001). From Constantinple to Lakedaimon Impressed White Wares, The Annual of the British School at Athens, Mosaic: Festschrift for A. H. S. Megaw. BSA 8: 57-67.

Auzepy M. F. (2006). Campagne de prospection 2005 de lamission monastéres Byzantins de la cote sud de la Marmara, Anatolia Antiqua XIV, 369-398.

Bass G. F. and Doorninck F. H. Jr. (1982). Yassi Ada, Vol. I, A Seventh Century Byzantine Shipwreck. Texas.

Böhlendorf-Arslan B. (2004). Glasierte Byzantinische Keramik Aus Der Turkei. İstanbul.

${ }^{15}$ For Karaağaçtepe, Türker 2009: 74, fig. 48; for Madytos, Türker 2010: 15-29; for Troia see Hayes 1995: 197-210, for Kepez see Türker 2013:361-374, for Sapan Hisar see Türker 2015, fig. 16, 18-19. The findings in the other settlements mentioned were detected by us during our surveys in the region. 
Böhlendorf-Arslan B. (2018). Gülpınar Pottery Again: Towards a Re-Evaluation of Local and Imported Wares, XIth Congress AIECM3 on Medieval and Modern Period Mediterranean ceramics Proceedings / XI. AIECM3 Uluslararası Orta Çă̆ ve Modern Akdeniz Dünyası Çanak Çömlek Kongresi Bildirileri 1, Vekam 52, 19-24 Ekim 2015, İstanbul: 279-290.

Cottica D. (1998). Ceramiche bizantine dipinte ed unguentari tardo antichi dalla 'Casa dei Capitelli' Ionici a Hierapolis, Rivista di Archeologia, XXII: 81-90.

Cottica D. (2007). Micaceous White Painted Ware from insula 104 at Hierapolis/Pamukkale, Turkey, Çanak - BYZAS 7. Eds. B. Böhlendorf-Arslan, A. O. Uysal, J. Witte-Orr; Istanbul: 255-272.

Cottica D. (2005). Perspectives on pottery production and Exchange in Late Roman and Byzantine Anatolia: The common wares from Hierapolis, Phrygia, LRCW I, Late Roman Coarse Wares, Cooking Wares and Amphorae in the Mediterranean Archaeology and Archaeometry. Eds. J. Ma. Gurt i Esparraguera, J. Buxeda i Garrigos, M. A. Cau Ontiveros, Oxford: 655-666.

Crow, J. G. (1995). The Long Walls of Thrace, Constantinople and Its Hinterland. London: 109-124.

Çömezoğlu Uzbek Ö. (2019). İstanbul Üniversitesi Yüzey Araştırması (İSTYA) Projesi Büyükçekmece Çalışmalarında Elde Edilen Çanak Çömlek Buluntular. İstanbul İli Yüzey Araştırması 2016-2017 Büyükçekmece. İstanbul: 91-113.

Dewing, H. B. (1971). Procopius, Buildings IV. Cambridge.

Doğer L. (2000). İzmir Arkeoloji Müzesi örnekleriyle kazıma dekorlu Ege-Bizans Seramikleri. İzmir.

Doğer, L. (2012). Daskyleion II. Hisartepe / Daskyleion Kazısı Bizans Seramikleri. İstanbul.

Fronçois V. (2003). La Céramique Byzantine et Ottomane. La Bithynie au Moyen Âge, Paris: 287-308.

Greatrex, G. (1995). Procopius and Agathias on the defences of the Thracian Chersonese. Constantinople and Its Hinterland. London: 125-129.

Hayes J. W. (1992). Excavations at Saraçhane in Istanbul. Princeton.

Hayes J. H. (1995). A Late Byzantine and Early Ottoman Assemblage From the Lower City in Troia. Studia Troica, 5, 197-210.

İnanan F. (2014). Zeuksippus Tipi Seramiklerin Anadolu'daki Dağılımları. Uludağ Üniversitesi Fen-Edebiyat Fakültesi Sosyal Bilimler Dergisi 26: 151-168.

İnanan F. and S. Seçkin (2021). Çobankale Kazısı Sırlı Seramik Buluntuları: İlk Gözlemler, Cedrus IX, 2021:437-458.

Isaac B. (1986). The Greek Settlements in the Thrace until the Macedonian Conquest. Leiden.

Kontogiannis N. D. and B. Böhlendorf-Arslan (2021). Kültürel Üretim Aracı Olarak Sırlı Kaplar: Geçmiş Araştırmalar, Güncel Durum ve Gelecekteki Sorunlar. Bizans, Selçuklu ve Osmanlı Topraklarında Kültürel Üretim Aracı Olarak Sırlı Kaplar, 13. Uluslararası Anamed Yıllık Sempozyumu, İstanbul: 3-24.

Köroğlu G. and F. İnanan (2018). Sinop Balatlar Kilise Kazılarında Ortaya Çıkarılan Seramikler, XIth Congress AIECM3 on Medieval and Modern Period Mediterranean ceramics Proceedings / XI. AIECM3 Uluslararası Orta Çă̆ ve Modern Akdeniz Dünyası Çanak Çömlek Kongresi Bildirileri 1, Vekam 52, 19-24 Ekim 2015, İstanbul: 319-327.

Koval V. Yu (October 2018), Byzantine vessel from Northern Russia (Poster), AIECM3 on Medieval and Modern Period Mediterranean Ceramics, Atina. 
Mastoropoulos, G. S. (1988). Siphon $>$ S(i)phouni Survival of Ancient (?) Vessel,

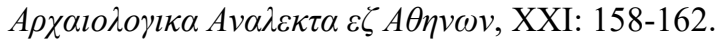

Megaw A. H. S. (1968). Zeuxippus Ware, The Annual of the British School at Athens, 63, 67-88.

Megaw A. H. S. (1975). An Early Thirteenth Century Aegean Glazed Ware, Studies in Memory of David Talbot Rice. Ed. G. Robertson, G. Henderson. Edinburg: 34-45.

Megaw A. H. S. and Jones R. E. (1983). Byzantine and Allied Pottery: A contribution by chemical analysis to problem of the origin and distribution. The Annual of the British School at Athens 78: 235-263.

Mercangöz Z. (2013). Archaeological Finds on Late Byzantine Commercial Productions at Kadıkalesi, Kuşadası, Byzantine Craftsman - Latin Patrons, Ed. Z. Mercangöz. İstanbul: $25-58$.

Özkul-Fındık N. (2014). İznik Sırlı Seramikleri, Roma Tiyatrosu Kazısı (1980-1995). Ankara.

Papanikola-Bakirtzi D. (1999). Byzantine Glazed Ceramics the Art of Sgraffito. Athens.

Papanikola-Bakirtzi D. and S.Y. Waksman, Thessaloniki Ware Reconsidered, Medieval and Post Medieval Ceramics in the Eastern Mediterranean: Fact and Fiction, Proceedings of the First International Conference on Byzantine and Ottoman Archaeology, Ansterdam 21-23 October 2011, 227-248.

Papanikola-Bakirtzi D. - Zikos, N. (2007). Late Byzantine Glazed Pottery from Thrace. Thessaloniki.

Türker A. Ç. (2009). Early Christian and Byzantine Archaeology on the Valleys around Madytos, Anadolu ve Çevresinde Ortaçă̆, 3, 51-74.

Türker A. Ç. (2010). Glazed Byzantine Pottery in Eceabat - Madytos, XII. Ortaçă - Türk Dönemi Kazllarl ve Sanat Tarihi Sempozyumu. İzmir: 15-29.

Türker A. Ç. (2013). Byzantine Pottery from Dardanos and Kepez in the Hellespontus, The Deltion of the Christian Archaeological Society, 34, 361-374.

Türker A. Ç. (2014). The Byzantine Castle in Akbaş on Thracian Chersonessos, Turkish Studies - International Periodical for the Languages, Literature and History of Turkish or Turkic, 9, 1-11.

Türker A. Ç. (2015). The Byzantine Castle on Granicus Valley: Sapan Hisar, Turkish Studies - International Periodical For the Languages, Literature and History of Turkish or Turkic, 10, 229-250.

Vroom J. (2006). Some Byzantine Pottery Finds From Kaman-Kalehöyük: A First Observation. Kaman Kalehöyük 15, 163-169.

Waksman S. Y. and Ç. Girgin (2008) Les Vestiges de Production de Céramiques des Foilles de Sirkeci (İstanbul). Premiers Elements de Caracterisation. Anatolia Antiqua XVI: 443-469.

Waksman S. Y. (2021). Konstantinopolis/İstanbul'da Çömlek Üretimi: Güncel Kazılar ve Modellerin ve Tekniklerin Yayılmasına dair yeni sorunlar, Bizans, Selçuklu ve Osmanlı Topraklarında Kültürel Üretim Aracı Olarak Sırlı Kaplar, 13. Uluslararası Anamed Ylllı Sempozyumu, İstanbul: 65-82.

Waksman S. Y. and V. François (2004-2005). Vers une redéfinition typologique et analytique des céramiques byzantines du type Zeuxippus Ware, Bulletin Correspondance Hellnique 128-129: 629-724.

Yenişehirlioğlu F. (1989), La céramique glaçurée de Gülpınar, Recherches sur la Céramique Byzantine. BCH Suppl. Vol. XVIII, Eds. V. Déroche, J. M. Spieser: 303-315. 

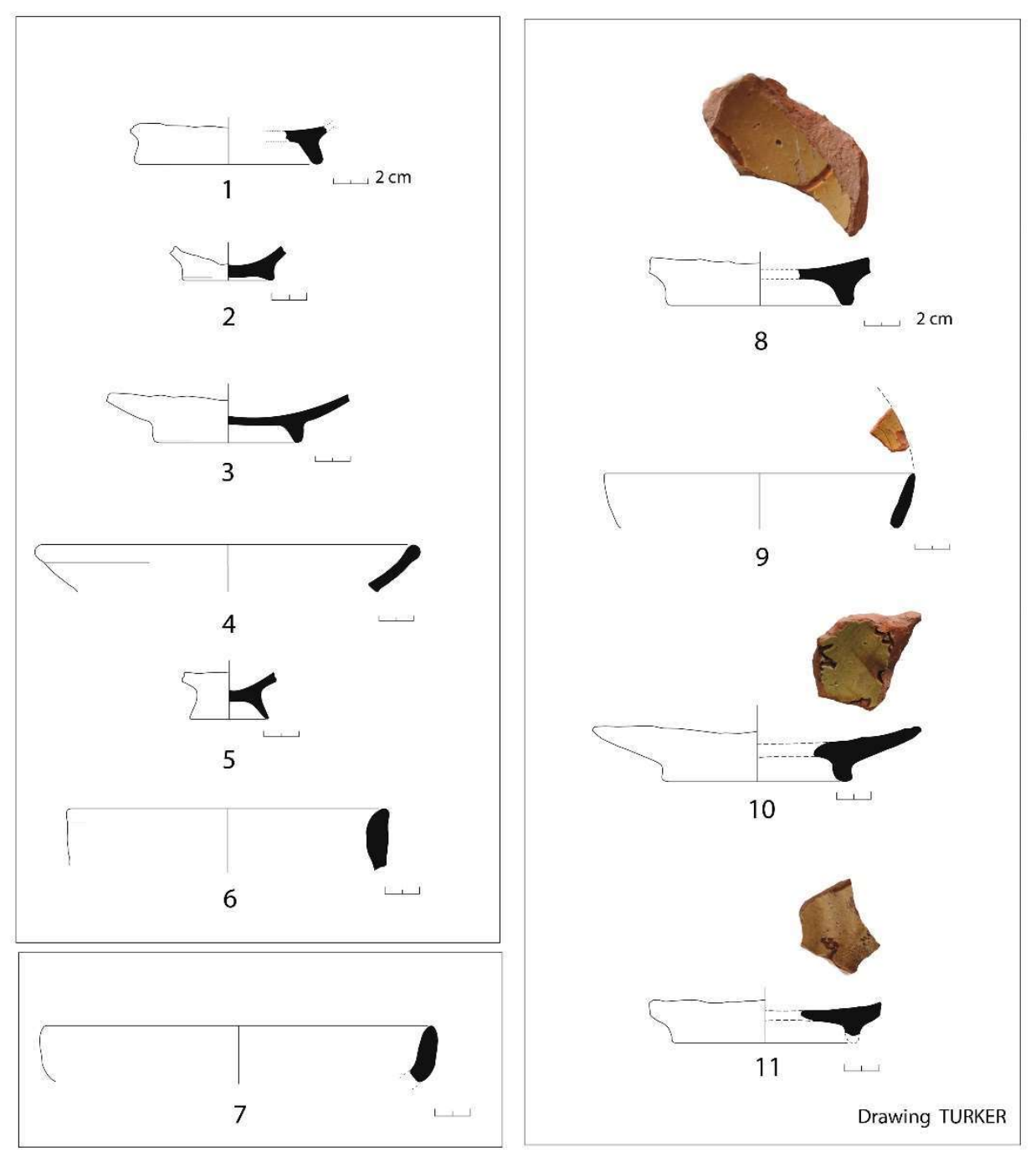

Figure 1 

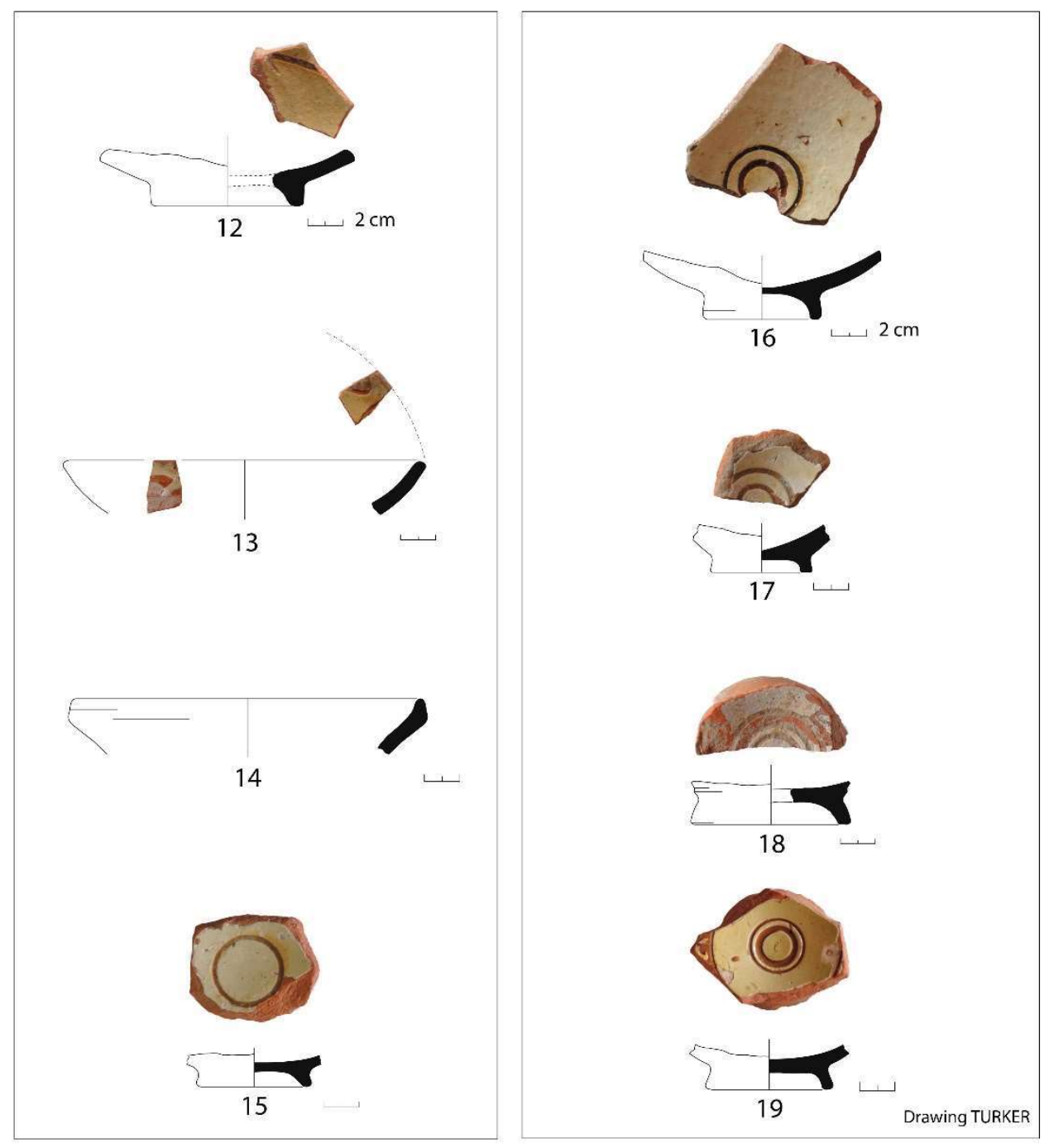

Figure 2 

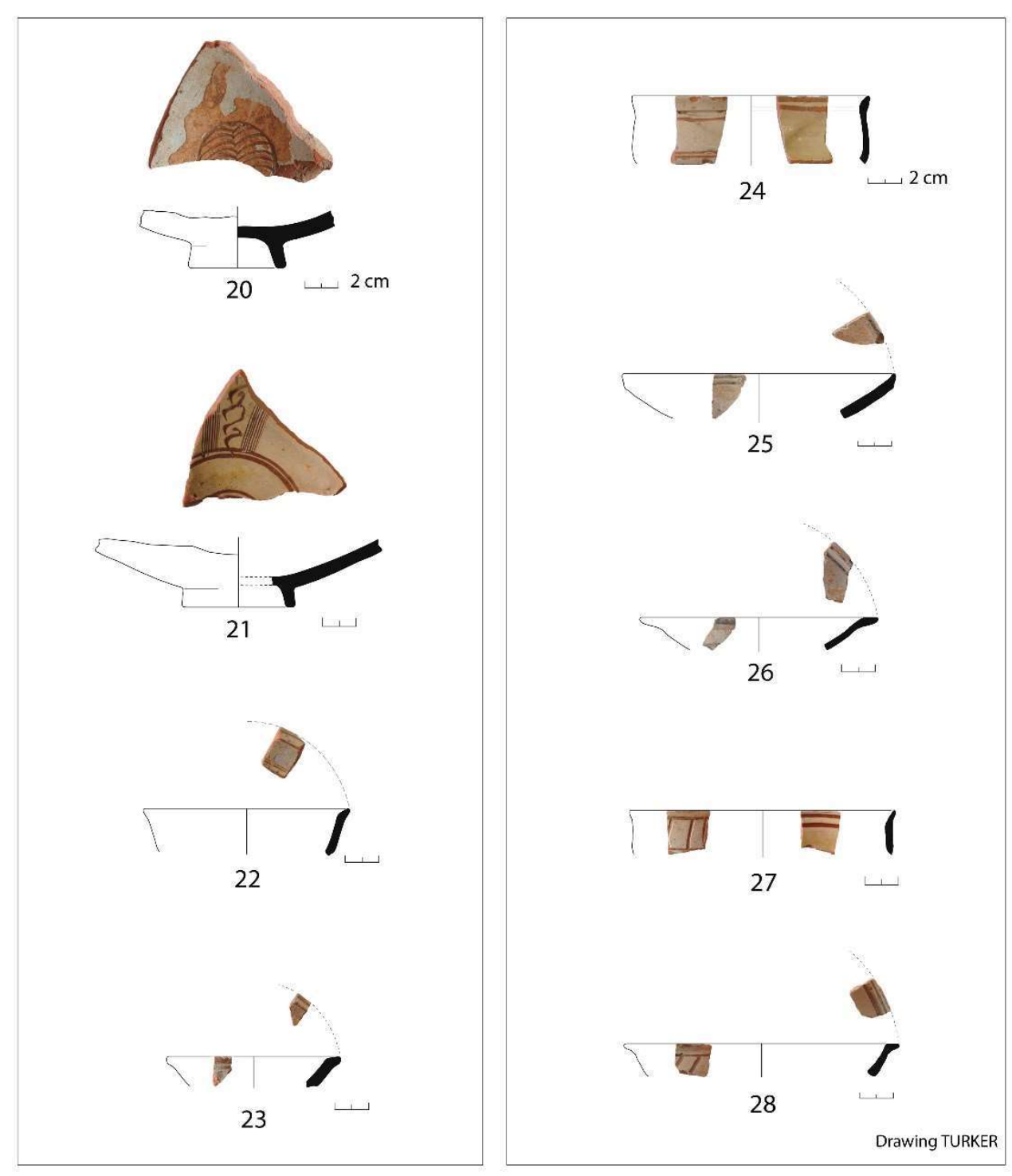

Figure 3 


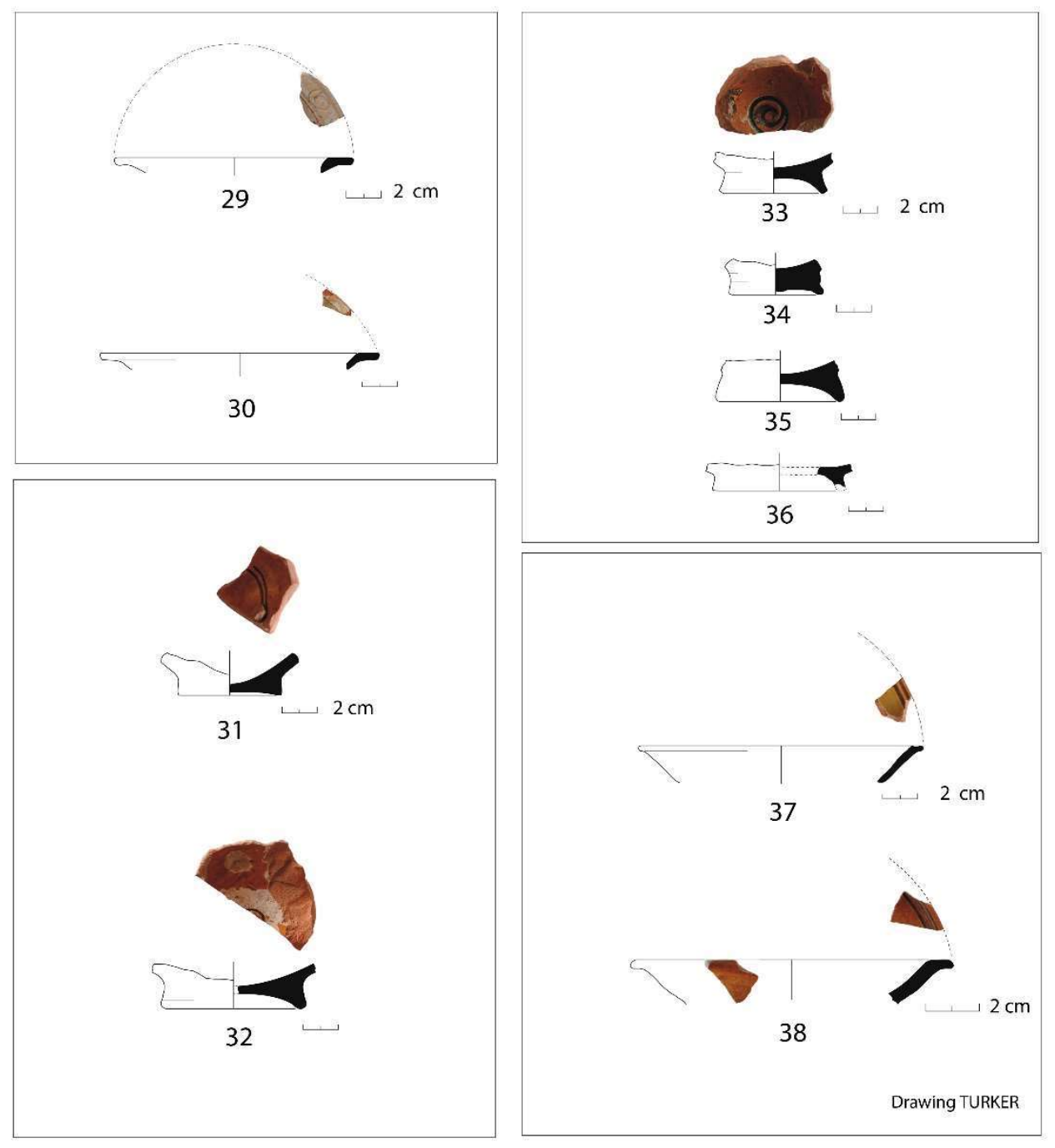

Figure 4 

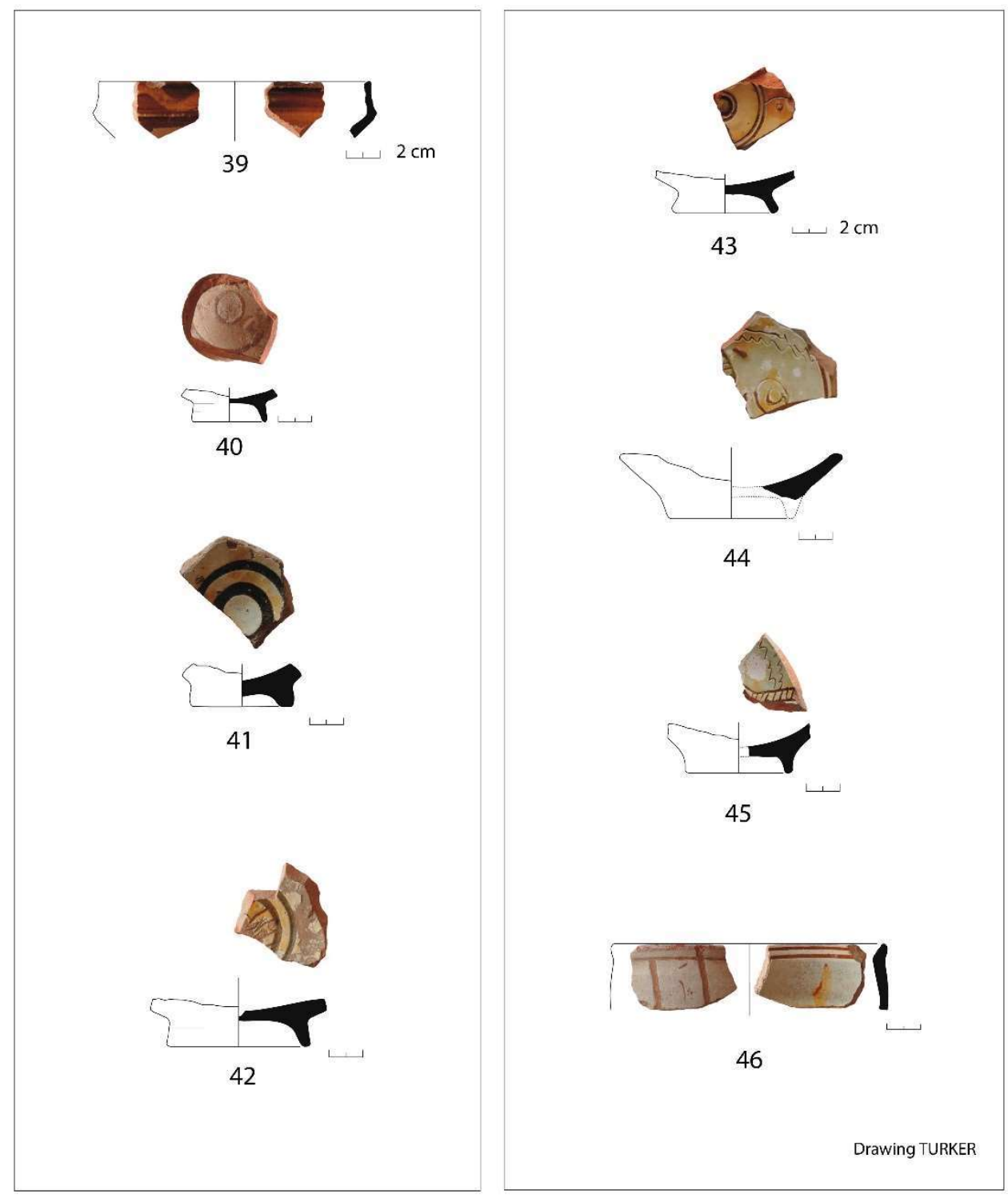

Figure 5 


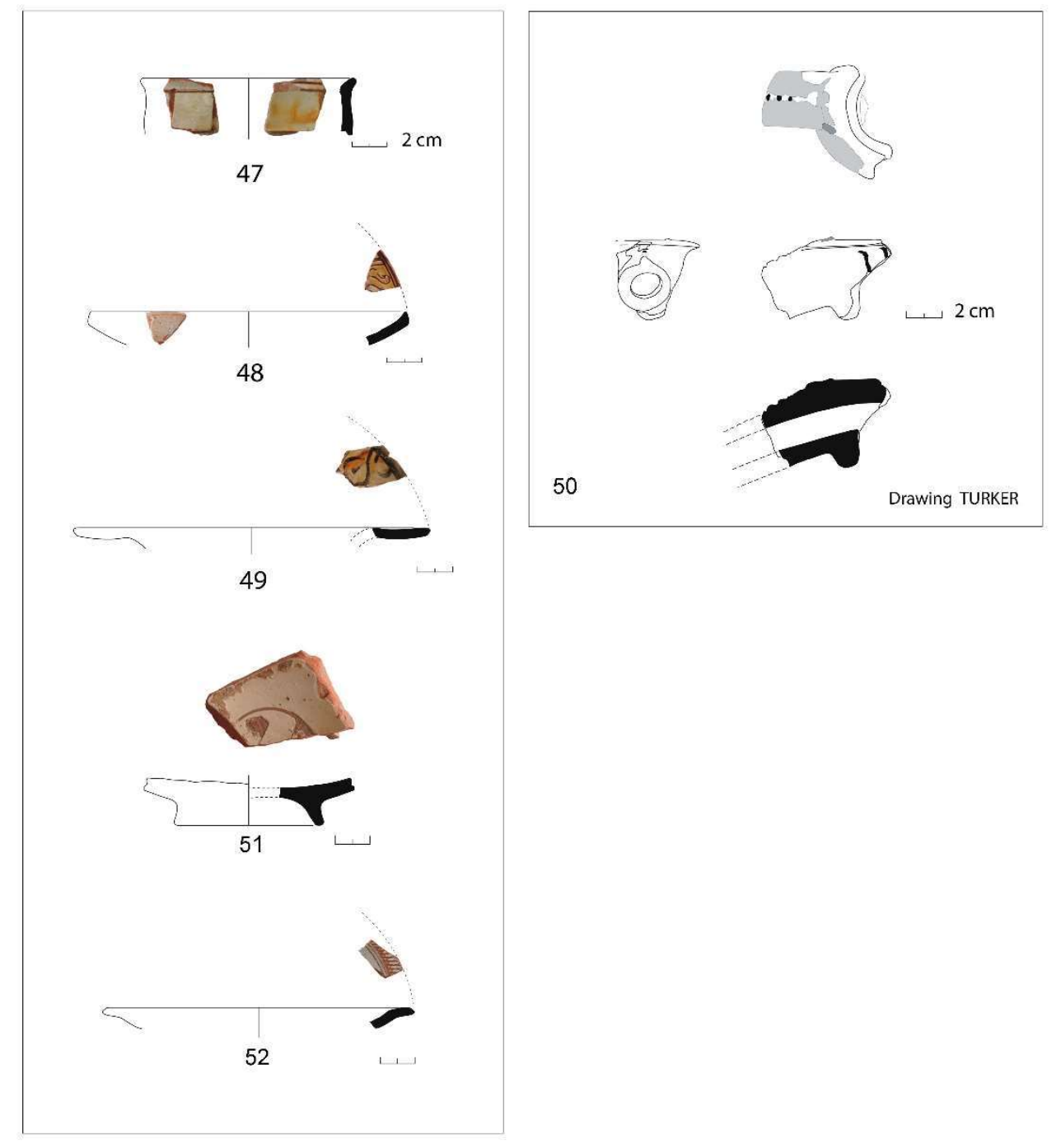

Figure 6 

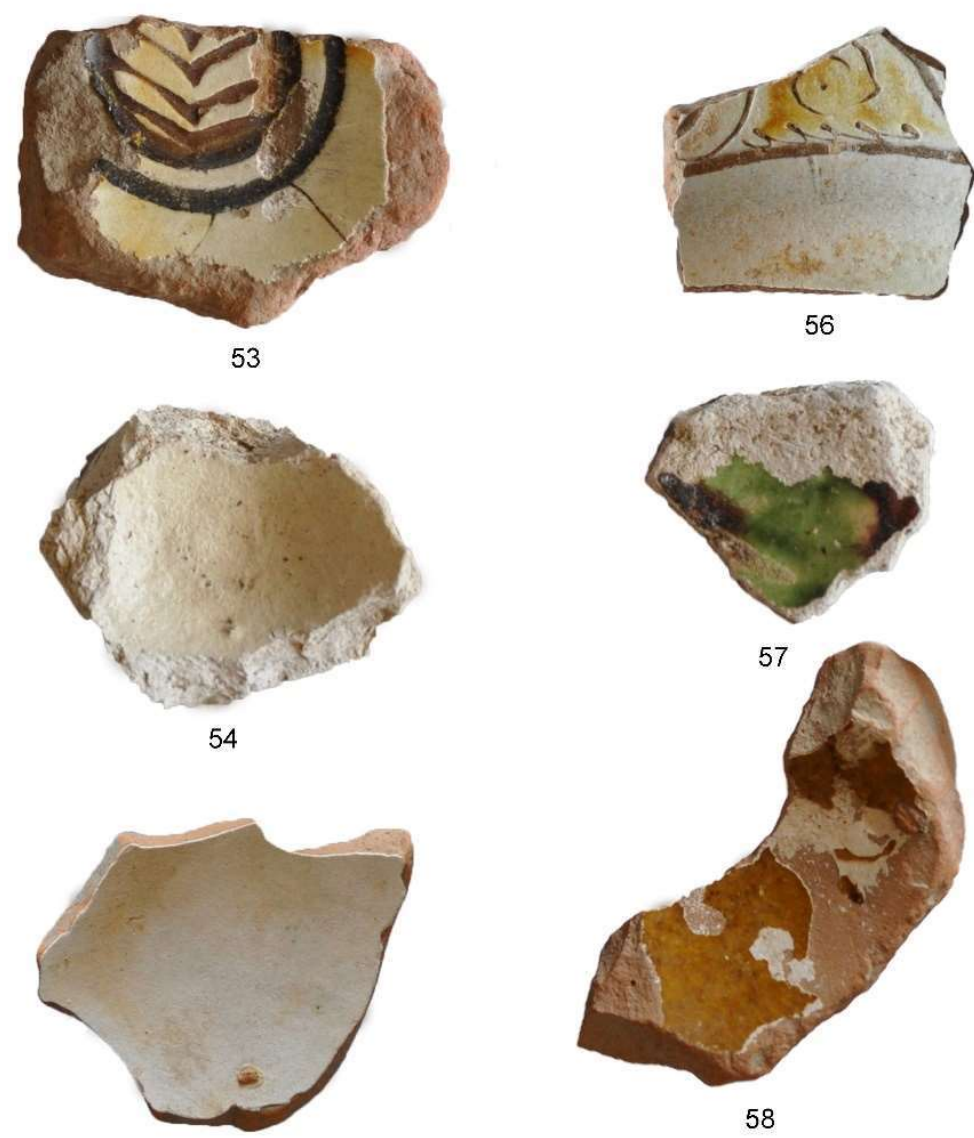

55
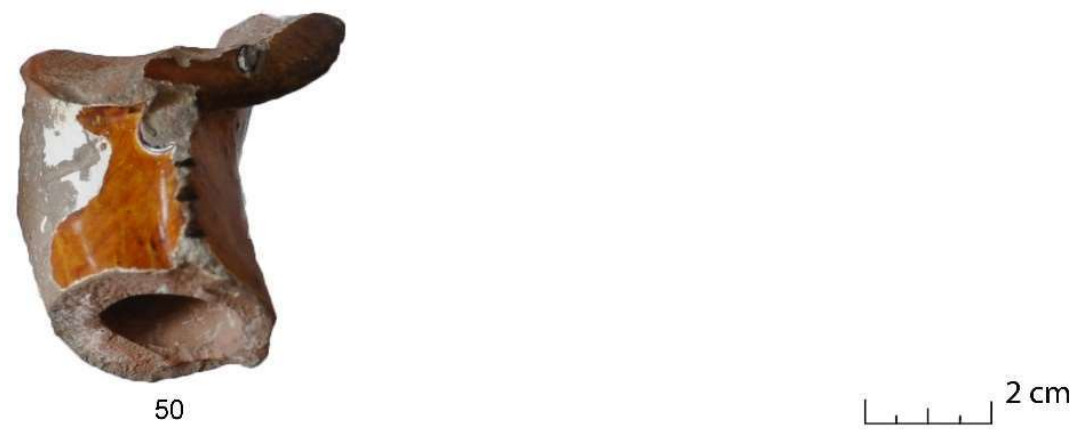

Figure 7 